\title{
The Design of New Cycloid Gear with Variable Cross Section and the Research of End Milling in Five-Axis Machine Tool
}

\author{
Lizhi Gu${ }^{1}$, Jianmin $\mathrm{Xu}^{1}$, Shanming $\mathrm{Luo}^{2}$ \\ ${ }^{1}$ College of Mechanical Engineering and Automation, Huaqiao University, Xiamen 361021. China. E-mail: gu- \\ lizhi888@163.com, xujianmin1020@163.com \\ ${ }^{2}$ School of Mechanical and Automotive Engineering, Xiamen University of Technology, Xiamen 361024. China. E-mail: \\ smluo@xmut.edu.cn
}

In order to improve the transmission efficiency and the service life of ordinary cycloid gear, 5 kinds of new cycloid gears with variable cross section are devoleped based on the principles of traditional cycloid drive. These new cycloid gears include concave cycloid gear, drum cycloid gear, spherical cycloid gear, oblique cycloid gear and cone cycloid gear. The general mathematical equations of these new cycloid gears are obtained and the characteristics of these new cycloid gears in transmission applications are analyzed in detail. A new method on the end milling tooth profile surfaces of cycloid gear using ball end mill is proposed. 5 axis numerical control simulations of these cycloid gears are conducted and the tool paths of machining cycloid gear are obtained. 5 kinds of cycloid gear with variable section are machined on five-axis CNC machining center, which verifies the correctness of the NC program. The study will provide a new way of designing and machining cycloid gear.

Keywords: The new cycloidal gear with variable section, End milling, Numerical control simulation.

\section{Acknowledgements}

This paper is supported by the National Natural Science Foundation of China (Grant No.51375411; 51205335).

\section{References}

[1] WANG W. S, FONG Z. H. (2008). A dual face-hobbing method for the cycloidal crowning of spur gears. In: Mechanism and Machine Theory, Vol.43, No.11, pp.1416-1430. PERGAMON-ELSEVIER SCIENCE LTD. ENGLAND.

[2] WANG W S, FONG Z H. (2011). Undercutting and contact characteristics of longitudinal cycloidal spur gears generated by the dual face-hobbing method. In: Mechanism and Machine Theory, Vol. 46, No. 4, pp.1416-1430. PERGAMON-ELSEVIER SCIENCE LTD. ENGLAND.

[3] HA LAN-TAO, SHI HA-I FENG, HUA Y-I SU, WEI JIAN, CHEN MIN. (2003). Research on Open CNC System for Cycloid Gear Grinder. In: JOURNAL OF SHANGHAI UNIVERSITY OF ENGINEERING SCIENCE, Vol. 17, No. 3, pp. 217-220. Editorial Department of Journal of Shanghai University of Engineering Science. China.

[4] CHEN BINGKU,I JIANG XUJUN, WANG SHUYAN.(2005). Introduction research on the new taper cycloidal gear planet transmission. In: Modern Manufacturing Engineering, Vol. 11, No. 2, pp. 14-15. Chinese Mechanical Engineering Society. China.

[5] CHEN BING-KUI, HU JUN-ZHANG, LI CHAO-YANG.(2009). Computerized numerical control programming system of cycloidal pin gear based on double-arc method. In: JOURNAL OF CHONG QING UNIVERSITY, Vol. 32, No. 11, pp. 1246-1251. Chongqing university press. China.

[6] LI GENGGENG, DENG XIAOZHONG, WEI BINGYANG, LI TIANXING, YANG JIANJUN.(2012). Efficient 5- axis NC Milling of Spiral Bevel Gears Using Disc Cutter with Concave End and Its Machining Simulation. In: China Mechanical Engineering, Vol. 23, No. 21, pp. 2607-2611. Chinese Mechanical Engineering Society. China.

[7] ZHENG YAO HUI, GAO LEI, LI XIAO PENG, WANG JING GANG. (2014). Cutting Force Prediction in Ball End Milling of Free Surface with Uncut Area. In: Modular Machine Tool and Automatic Manufacturing Technique,Vol. 13,No. 2, pp. 125-128. Chinese Mechanical Engineering Society. China.

[8] CAO ZHI-MEI. (2014). Research on Programming Technology of Surface Machining Based on Constant Scallop Height. In: Modular Machine Tool and Automatic Manufacturing Technique, Vol.13, No.8, pp. 37-45. Chinese Mechanical Engineering Society. China.

[9] XU RUFENG, CHEN ZHITONG. (2014). Method of Five-axis Tool Radius Compensation Based on Post-processor.In: JOURNAL OF MECHANICAL ENGINEERING, Vol. 50, No. 13, pp. 157-164. Chinese Mechanical Engineering Society. China. 
[10] HSIEH J F. (2013). APPLICATION OF HOMOGENOUS TRANSFORMATION MATRIX TO THE MODELING OF A BALL-END CUTTER.In: Transactions of the Canadian Society for Mechanical Engineering, Vol. 37, No. 3, pp. 775-785. Canadian Society for Mechanical Engineering. Canada.

[11] HSIEH, C. F. (2015). Traditional versus improved designs for cycloidal speed reducers with a small tooth difference: The effect on dynamics.In: Mechanism and Machine Theory, Vol. 86, No. 11. pp. 15-35. PERGAMONELSEVIER SCIENCE LTD. ENGLAND.

[12] KAZAKYAVICHYUS, S. M., STANOVSKOY, V. V., REMNEVA, T. A., KUZNETSOV, V. M., BUBENCHIKOV, A. M., SHCHERBAKOV, N. R. (2011). Performance of eccentric-cycloid engagement with change in the interaxial distance: Modification of tooth configuration. Russian Engineering Research, Vol. 31, No. 3, pp. 197-199.Springer. Netherlands.

[13] YANG, G. L., ZHANG, X. L., FAN, J. Y., ZHU, L. H., CHEN, Q., LI, W. Q. (2014). Parameter Design of Tooth Profile for Internal Cycloid Gear Pump with Multi-Teeth Difference. In: Applied Mechanics and Materials, Vol. 687, No. 3. pp. 13-17. TTP. Switzerland.

[14] WANG, J. B., YIN, J. S., YU, C. (2013). Fuzzy Robust Design of Cycloid Pin Wheel Reducer Based on Genetic Algorithms. In: Applied Mechanics and Materials, Vol. 325, No. 2. pp. 319-324. TTP. Switzerland.

[15] LUKOVICS, P. (2013). Evaluation of vibration on technological devices. In: Manufacturing Technology, Vol. 14, No. 3, pp. 345-349.

[16] SHAN, C. J., BIAN, Y. D., LI, L. (2014). Part Design and Analysis of Cycloid Installation Systems. In: Applied Mechanics and Materials, Vol. 539, No. 2. pp. 51-54. TTP. Switzerland. 